Ming Cheung* and William McCarthy

\title{
"Authentically Disney, distinctly Chinese" and faintly American: The emotional branding of Disneyland in Shanghai
}

https://doi.org/10.1515/sem-2017-0059

\begin{abstract}
Since the 1980s Disney has opened a new overseas theme park every decade. After finding success in Tokyo in 1983, subsequent parks in Paris and Hong Kong have struggled to profit financially and connect culturally with locals. For Shanghai in 2016, Disney utilized a new discourse for the park's development and configuration termed "authentically Disney, distinctly Chinese." In this paper, Disney's emotional branding strategy for Shanghai Disneyland is analyzed using a framework of five antecedents for creating affective attachment to brands. In addition, the pragmatics of the dyadic phrase and the intertextuality of the park's composition demonstrate that unlike previous international Disneylands, Disney blurred and removed cultural and contextual references to America from Shanghai in an effort to achieve resonance with Chinese visitors. The result is China's Disneyland, not Disneyland in China. Though Shanghai's revenue and attendance figures are good so far, Disney will likely face challenges to its new emotional branding strategy from within China and the US.
\end{abstract}

Keywords: Disneyland, China, globalization, emotional branding, culture, theme parks

\section{Introduction}

A new Disneyland opened in 2016 in Shanghai, China, uniquely differentiated from previous international Disneylands. While Tokyo Disneyland (TDL) has been a financial success since its 1983 opening, Disneyland Paris (DLP) and Hong Kong Disneyland (HKDL) have been financially problematic and culturally contested by locals since their respective openings in 1992 and 2005 (Barboza

\footnotetext{
*Corresponding author: Ming Cheung, Griffith University, Brisbane/Gold Coast, Australia, E-mail: m.cheung@griffith.edu.au; drmingcheung@gmail.com William McCarthy, University of Adelaide, Adelaide, Australia, E-mail: william.mccarthy@adelaide.edu.au http://orcid.org/0000-0002-9046-0603
} 
and Barnes 2016; Choi 2010a; Lainsbury 2000). While the semiotic playbook of Disneyland was a success in Japan, it faltered in Disney's last two international forays. At the groundbreaking ceremony for Shanghai Disneyland (SHDL) on 8 April 2011, Disney CEO Bob Iger dictated that the new park would be different by being "authentically Disney and distinctly Chinese." The phrase became emphasized so incessantly during the development and construction of SHDL that it was posted on bulletin boards throughout the Disney corporate offices in Shanghai (Barboza and Barnes 2016). It was not readily apparent what the phrase meant as a branding departure for Shanghai. Tokyo, Paris, and Hong Kong were all created as seemingly authentic Disney parks with famous Disneyland attractions such as Space Mountain, It's a Small World, and the Mad Tea Party, and familiar lands including Fantasyland, Adventureland, and Frontierland. The international parks were distinct to their locales using the local language in attraction and show dialogues. Front-line park employees were conversant in the local language. Food and beverages included local fare as well as American comfort food. Bryman's (2004) four dimensions of Disneyization were evident in all the Disney parks, domestic and international: theming, hybrid consumption, merchandising, and performative labor. Therefore, the phrase "authentically Disney, distinctly Chinese" meant more than a surface reading would indicate as the previous international Disneylands also seemed authentically Disney with local cultural practices. This paper argues that the phrase indicates a new emotional branding strategy by Disney for SHDL. This Chinese Disneyland, rather than Disneyland in China, would distinguish itself by showcasing new rides and attractions rather than transplanted clones from existing Disneylands, blurring and disconnecting the American essence of Disneyland, and emotionally comforting Chinese visitors.

In this paper, we first examine emotional branding as a means to forming visceral resonance between a company's product and consumers. Then the background of the three pre-SHDL international parks (Tokyo, Paris, and Hong Kong) and Disney's efforts at connecting to the locals are explicated. The successes and failures of the positioning and design of previous parks provide a historical context for how Disney approached Shanghai. The tortuous and turbulent history of Disney's negotiation with the Chinese government to build a park is discussed. Grisaffe and Nguyen's (2011) five antecedents for creating emotional attachment to a brand is utilized as a framework of analysis to examine SHDL. For reference in the analysis, SHDL's attractions are categorized for originality compared to previous Disneylands, and evidence of Chinese symbols and American content. Consideration is also given to the pragmatics of the "authentically Disney, distinctly Chinese" phrase and the park's intertextuality. The discussion section extrapolates the analysis to a semiotic 
square to locate the unique positioning of SHDL compared to previous international Disneylands. The conclusion notes the thus far promising financial and attendance results of SHDL while positing potential threats to the early success of the "authentically Disney, distinctly Chinese" emotional branding from other theme park developments in China, and the America-first administration of President Donald Trump.

\section{Emotional branding}

A brand is a sign that interacts with a consumer through a symbolic process underlining the satisfaction of social and emotional benefits that other brands cannot satisfy (Oswald 2012). When this symbolic appeal fulfills a consumer's emotional desires, a brand can establish a resonant connection leading to considerable financial reward for the company. When entering international markets, a brand's domestic symbolic associations can limit its appeal to a new audience, thus careful attention must be paid to contextual and cultural adaptation (Cheung 2012). Emotional branding became popular in the 1990s as a way of overcoming the problems of traditional benefit-driven marketing strategies (Gobe 2001). A product's touted benefits can be matched by competitors, but the establishment of a consumer-brand link at the sensory level of storytelling enables companies to create strong, long-lasting attachments resistant to brand-switching (Roberts 2004; Morrison and Crane 2007). Going beyond a product's benefits vis-à-vis competitors, emotional branding uses "narratives and tactics that demonstrate an empathetic understanding of customers' inspirations, aspirations, and life circumstances and that generate warm feelings of community among brand users" (Thompson et al. 2006). Fournier's (1998) study identifies the vocabulary of relationships (love/passion, self-connection, commitment, interdependence, intimacy, and partner quality) as applicable to branding connections. In a highly saturated media environment full of advertising pitches, emotional branding can cut through the clutter to appeal to the consumer on a personal and holistic level (Thompson et al. 2006). Roberts (2004) advises brand strategists to focus their brand on the lives, dreams, and ambitions of consumers to create a compelling, proactive connection. Atkin (2004) suggests companies like Apple have succeeded in creating within consumers a cult-like level of devotion for the brand. Research on emotional branding has focused on consumer product companies such as Tide, Nike, Apple, Cheerios, McDonald's, and Starbucks (Gobe 2001; Atkin 2004; Roberts 2004; Thompson et al. 2006), and 
Wasko et al. (2001) focused on Disney as a global, and identifiably American, brand in an international audience reception study. But Disneyland itself has not been looked at as an emotional brand. Like other brands, Disneyland is a physical and mental construct packed with meanings that can resonantly connect with visitors.

\section{Disney's international parks}

\subsection{Tokyo, Paris, and Hong Kong Disneylands}

Before Shanghai, Disney opened Magic Kingdom style castle parks in three international locations: Tokyo Disneyland (TDL) in 1983, Disneyland Paris (DLP) in 1992, and Hong Kong Disneyland (HKDL) in 2005. Disney's discourse surrounding each park's opening, approach to local cultural issues, and financial results put into context the company's later positioning of the Disneyland brand in Shanghai.

Disney's first international park in Tokyo was forged as a licensing agreement with the Japanese firm, Oriental Land Company (OLC is a partnership between Mitsui Real Estate Development and Keisei Electric Railway). TDL is the only international Disney park wholly owned by a local company with Disney only receiving a relatively small percentage of the entrance ticket and food/beverage sales (Raz 1999). For the design of the park, Disney Imagineers (the research and development department of the Disney company) proposed a Samurai Land and a Ginza District (instead of Main Street USA) but OLC wanted to appropriate Disney for a Japanese audience while keeping the park as close as possible to the American Disneyland (Raz 1999). Brannen (1992) cites this phenomenon as "keeping the exotic exotic" so Japanese could feel as if they were taking a foreign vacation while still in Japan. TDL was only "Japanized" by making minor modifications to shows and attractions for a Japanese audience (primarily the dubbing of Japanese for language tracks), dovetailing Japanese cultural aspects of work behavior, management practices, and labor relations with existing Disney employee philosophy, and running successful marketing campaigns to Japanese to make repeat visits to the park (Raz 1999). The park was edited for Japan's consumer culture by the incorporation of omiyage (gift-giving for friends, relatives, and co-workers while on vacation) customs into the park's retail merchandising and cash wrap procedures (Brannen 1992). Prior to TDL's opening, the licensing negotiations between OLC and Disney had been contentious and the Japanese media 
predicted the park's failure, but upon opening the park was an immediate success with a million visitors in only the first month of operation and the licensing terms, upon reflection, were considered quite favorable to the Japanese (Raz 1999). Most of the park's attractions were clones of American Disneyland favorites, but three had Japanese characteristics. One was a 19minute audio-animatronic show in Tomorrowland called "Meet the World" that told the story of Japan's encounters with foreign countries. Second was a Tomorrowland film called "The Eternal Sea” that explored humanity's relationship with bodies of water, an environmentally relevant topic for an island nation. Third was a 15-minute "Mystery Tour" through Cinderella's Castle that enlisted park visitors into the role of fighting and defeating an evil force. This castle tour was culturally familiar to locals as a traditional Japanese ghost-house (obakeyashiki; Raz 1999). Over time all three of these distinctly Japanese attractions closed (the last one in 2006), but the attendance and revenue numbers for TDL remain among the highest in the world for any theme parks (TEA 2017). Disney's success at TDL with Japanese visitors and employees in a park very similar to the American ones encouraged Disney to attempt another international expansion.

Disney chose Paris, France, for the next international park due to its central location in Europe and anticipation of British visitors coming through the then under construction Channel Tunnel. Lainsbury (2000) chronicled the turbulent genesis of Euro Disneyland, which Paris theater director Ariane Mnouchkine famously called "a cultural Chernobyl." Even the park's original name "Euro" caused problems as the American perception of the word "Europe" implied glamor and style, while Europeans associated the term with business and commerce (Lainsbury 2000). Within two years of opening, the park was given a new name, Disneyland Paris. The name change did little to solve the park's financial and cultural problems. In Brannen's (2004) study of the recontextualization of Disney's international parks, the Japanese saw Disney's service orientation, personnel management and training as culturally normative, while the French perceived it as totalitarianism, invasiveness, and abnormalness. In Japan, souvenirs were a part of memento and omiyage cultural norms, while the French saw them as tacky and a waste of money. Assuming the same playbook from Japan would suit French and European visitors, almost all opening day attractions were clones or very similar to other Disney parks. French visitors balked at the Disney tradition of not serving alcoholic beverages in Magic Kingdom style parks (a rule dictated by Walt Disney himself), so the prohibition had to be lifted a year after the park's opening. Disney assumed that European visitors would have habits similar to Americans, such as wanting only a simple grab-and-go continental breakfast in the park. American park managers discovered the hard way that Europeans 
wanted a sit-down restaurant breakfast meal when hotel eateries were mobbed every morning with extremely long wait lines for service. Merchandise sales were slow as French visitors rejected the bland colors on clothing that Disney purposely designed as tasteful and understated, and instead demanded bright and colorful tshirts with Mickey and Goofy (Lainsbury 2000). Rather than being happy within Disney culture, French visitors and workers chafed under a Disney park that was not suitably French in character or behavior, leading DLP to hemorrhage financially. Disney discovered the French were not like the Japanese.

After being rebuffed by China for a park in the 1990s, Disney settled on Hong Kong as second best in proximity to the China market. Choi's (2010b) discourse analysis of Hong Kong periodicals and government pronouncements leading up to the agreement with Disney to build a park revealed the framing of Hong Kong's desire to be considered a "world city" after the 1997 handover to China and competition for prominence with China's other large cities, such as Shanghai. The underlying assumption was that a Disneyland park in Hong Kong was necessary to support this global ambition and marketing strategy of being Asia's world city. From the signing of the agreement through the park's first few years, there was a great deal of friction as the Hong Kong government and people saw the Disney company as being high-handed in its American management techniques, insensitive to local culture, and a disingenuous partner that foisted burdensome, opaque and unfair terms on Hong Kong (Choi 2010a, 2010b). The park's complement of attractions at its debut included almost nothing that did not already exist in another Disney venue. Most of the park's exterior structures, including its Sleeping Beauty Castle and Main Street, were copies of California Disneyland (CADL), while its land area and attraction count were the smallest, by far, of any Disney Magic Kingdom style parks. There was nothing to distinguish HKDL at its opening, and additions in the first few years were primarily clones from other Disney parks. A major expansion in 2012 and 2013 added areas unique to HKDL and a new night-time parade debuted in 2014. But since then a lull in major new attractions has coincided in a significant drop in revenue and attendance in 2015 (Hong Kong Disneyland 2016) and 2016 (Hong Kong Disneyland 2017). HKDL has also suffered from competition with a local competitor, Ocean Park, which is seen as a park for locals whereas Disney is seen as an American import at best, and cultural imperialist at worst (Choi 2010a).

After achieving a hit in Tokyo, Disney suffered two expensive misfires in Paris and Hong Kong for which the company continues to sort out financially to this day (Barboza and Barnes 2016). Undaunted, Disney was still determined to open a park inside China, but this time would implement a new branding strategy and park composition. 


\subsection{Shanghai Disneyland}

While Snow White and the Seven Dwarfs was screened in China in the late 1930s, there was limited awareness of Disney during the 1940s until the 1980s due to World War II, civil war, and the Communist victory in 1949 (Barboza and Barnes 2016). Mickey Mouse did not appear on CCTV Chinese television until 1986 (Areddy and Fritz 2016), so older generations had little historical affinity or knowledge of Disney media and products (unlike audiences in Japan, Europe, and Hong Kong). By the 1990s, then Disney CEO Michael Eisner saw China as an important emerging market for the company's operations, particularly for copyright concerns and a theme park (Stewart 2005). While Disney engaged in talks with Chinese officials over business interests in China, a controversy erupted over Disney's backing of Hollywood director Martin Scorsese's 1997 film Kundun. The Chinese government derided the film's depiction of the young Dalai Lama's flight from Tibet to India after the Chinese Communist takeover in the early 1950s, and threatened Disney's business interests in China if Eisner did not cut support for the film's distribution (Barboza and Barnes 2016). Not wanting to be seen capitulating to censorship demands, Eisner stood behind the film in public, but provided little funding to market the film and fumed behind the scenes at an apparent lost chance in China (Stewart 2005). Eisner hired former US Secretary of State Henry Kissinger to assuage Chinese concerns and to assure that Kundun would "die a quiet death" (Stewart 2005: 272). The film grossed less than US\$6 million at the US box office, but the damage had already been done to Disney's potential new business ventures in China, including a theme park.

After Iger took over as Disney CEO in 2005, he still viewed the China market as key for company growth and a prime location for a Disney theme park, even though the Hong Kong park had gone through financial ups and downs since its 2005 opening. Iger adroitly cultivated a personal relationship with Chinese President Xi Jinping leading to a 2009 agreement on a park in Shanghai with much more favorable terms for the Chinese government (Barboza and Barnes 2016) than the one Hong Kong agreed to in 1999 (Choi 2010a). At the 2011 groundbreaking ceremony, Iger coined the slogan, "authentically Disney, distinctly Chinese" that would be repeated constantly in connection to the design and construction process of SHDL until the June 2016 opening (Barboza and Barnes 2016) and even afterwards in the park's press releases (Frater 2016). Since becoming CEO in 2005, Iger has engineered the purchase of four important media content firms: Pixar, Marvel, Lucasfilm, and 21st Century Fox. One of his last major projects before his contract's presumed end in 2021 (the Disney board has already extended his contract four times) has been to build a strong brand foundation in China with SHDL as the showcase offering. 


\section{Method of analysis}

Table 1 categorizes each SHDL attraction for its relative distinctiveness compared to previous Disneylands, co-option (Frank 1997; Danesi 2006) of Chinese symbols, and presence of American content. The table findings provide a detailed overview of the park's attractions to ascertain in what manner Disney abided the antecedents of brand attachment. While Thomson et al. (2005) identify passion, connection and affection for measuring consumers' emotional attachment to brands, Grisaffe and Nguyen (2011) posit five controllable, qualitative antecedents that create bonding in the first place. Drawing on attachment theory in psychology (Bowlby 1969; Thomson et al. 2005), brand strategists strive to induce an emotional attachment leading to extreme loyalty. Grisaffe and Nguyen's (2011) five antecedents that create emotional attachment to brands include:

1. Sentimentality/emotional memory: nostalgia, childhood memories, recall of positive and warm memories, association with past good times, meanings from the past come to today's fruition, and meaningful people, places and situations.

2. Socialization: family as the social group, family tradition, collective grouping, social rituals, and group meanings.

3. User-derived benefits: accomplishing personal and/or functional goals, meeting needs, augmenting a situation, achieving safety, comfort, taste/ flavor and security, identifying support, reflecting real self/role, projecting desired self/role, attaining extension of self, and augmenting selfpresentation.

4. Traditional customer outcome: value for money, satisfaction with brand/ offering, competitive superiority, unique differentiation, unsurpassed, category-defining standard, and better than other brands tried.

5. Superior marketing characteristics: product quality, fulfilling promise, consistent performance, trusted, style/aesthetics, availability, convenient location, innovative, good service, and continuous improvement focus.

Grisaffe and Nguyen (2011) note that sentimentality and socialization are the most difficult for a brand to control due to individual idiosyncrasy and situational context, while the other three have mixed controllability by the branding company. None of their study's respondents discuss theme parks or other types of entertainment venues, instead focusing on consumer products and food/beverage outlets found at most shopping malls. The five antecedents as related to SHDL are detailed separately as to their execution. In addition, within this framework, the pragmatics of the "authentically Disney, distinctly Chinese" phrase is explicated 
Table 1: SHDL attraction breakdown as clone, adaptation/upgrade or new, presence of Chinese characteristics and American content.

\begin{tabular}{|c|c|c|c|c|c|}
\hline SHDL Attraction * & Clone & $\begin{array}{l}\text { Adaptation/ } \\
\text { Upgrade }\end{array}$ & New & Chinese Symbols ** & $\begin{array}{l}\text { Distinctly } \\
\text { American }\end{array}$ \\
\hline $\begin{array}{l}\text { Garden of the } \\
\text { Twelve Friends }\end{array}$ & & & $x$ & Garden; Chinese zodiac & \\
\hline $\begin{array}{l}\text { Enchanted } \\
\text { Storybook Castle }\end{array}$ & & $\mathrm{x}$ & & $\begin{array}{l}\text { Hua Mulan portrait; } \\
\text { Symbols (dragons with } \\
\text { pearls, jade, patterns, } \\
\text { peony) }\end{array}$ & $\begin{array}{l}\text { Princess Tiana, } \\
\text { Pocahontas }\end{array}$ \\
\hline $\begin{array}{l}\text { Voyage to the } \\
\text { Crystal Grotto }\end{array}$ & & & $x$ & Hua Mulan segment & Mickey Mouse \\
\hline $\begin{array}{l}\text { Seven Dwarfs Mine } \\
\text { Train }\end{array}$ & $x$ & & & & \\
\hline Peter Pan's Flight & & $x$ & & & \\
\hline Winnie the Pooh & $\mathrm{x}$ & & & & \\
\hline $\begin{array}{l}\text { Frozen Sing-Along } \\
\text { Celebration }\end{array}$ & & & $x$ & $\begin{array}{l}\text { Chinese string } \\
\text { instruments }\end{array}$ & \\
\hline $\begin{array}{l}\text { Alice in Wonderland } \\
\text { Maze }\end{array}$ & & $\mathrm{X}$ & & & \\
\hline Hunny Pot Spin & & $x$ & & & \\
\hline $\begin{array}{l}\text { Ignite the Dream } \\
\text { Fireworks }\end{array}$ & & & $x$ & Hua Mulan segment & Mickey Mouse \\
\hline $\begin{array}{c}\text { Mickey’s Storybook } \\
\text { Express Parade }\end{array}$ & & & $x$ & Hua Mulan segment & $\begin{array}{l}\text { Mickey Mouse, } \\
\text { Toy Story } \\
\text { (Woody) }\end{array}$ \\
\hline Fantasia Carousel & & $\mathrm{X}$ & & & \\
\hline $\begin{array}{l}\text { Dumbo the Flying } \\
\text { Elephant }\end{array}$ & $\mathrm{x}$ & & & & \\
\hline $\begin{array}{l}\text { Once Upon a Time } \\
\text { Adventure }\end{array}$ & & & $\mathrm{x}$ & & \\
\hline Camp Discovery & & & $x$ & & \\
\hline $\begin{array}{l}\text { Soaring Over the } \\
\text { Horizon }\end{array}$ & & $\mathrm{X}$ & & $\begin{array}{l}\text { Great Wall; Shanghai } \\
\text { skyline }\end{array}$ & $\begin{array}{l}\text { Monument } \\
\text { Valley, Utah }\end{array}$ \\
\hline Roaring Rapids & & & $x$ & & \\
\hline Explorer Canoes & $\mathrm{x}$ & & & & \\
\hline Siren's Revenge & & & $x$ & & \\
\hline Shipwreck Shore & & & $x$ & & \\
\hline $\begin{array}{l}\text { Pirates of the } \\
\text { Caribbean Battle } \\
\text { for the Sunken } \\
\text { Treasure }\end{array}$ & & $x$ & & & \\
\hline TRON Realm & & & $x$ & & Chevrolet cars \\
\hline
\end{tabular}


Table 1: (continued)

\begin{tabular}{|c|c|c|c|c|c|}
\hline SHDL Attraction * & Clone & $\begin{array}{l}\text { Adaptation/ } \\
\text { Upgrade }\end{array}$ & New & Chinese Symbols ** & $\begin{array}{l}\text { Distinctly } \\
\text { American }\end{array}$ \\
\hline $\begin{array}{l}\text { TRON Lightcycle } \\
\text { Power Run }\end{array}$ & & & $x$ & & \\
\hline Stitch Encounter & $x$ & & $x$ & & \\
\hline $\begin{array}{l}\text { Buzz Lightyear } \\
\text { Planet Rescue }\end{array}$ & & $x$ & $\lambda$ & & \\
\hline $\begin{array}{l}\text { Eye of the Storm: } \\
\text { Captain Jack's } \\
\text { Stunt Spectacular }\end{array}$ & & & $x$ & & \\
\hline $\begin{array}{l}\text { Tarzan: Call of the } \\
\text { Jungle }\end{array}$ & & & $x$ & Acrobatics & \\
\hline $\begin{array}{l}\text { Total } \\
\quad \text { Attractions }=28\end{array}$ & 5 & 8 & 15 & 8 & 6 \\
\hline
\end{tabular}

* Attractions include shows, fireworks, play areas, parade, walkthroughs, rides (flat, dark, coaster), but not character meet-and-greets.

** Besides the use of Mandarin Chinese in dubbed dialogue.

by looking at its meaning within the social, situational and textual context of the speaker and listeners (Paltridge 2006), and the implicit and explicit intertextual (Bakhtin 1986; Lemke 1992; Fairclough 1992) readings throughout the park’s lands and attractions are discussed.

\section{SHDL'S attraction categorization and Chinese symbols}

Table 1 lists the 28 attractions of SHDL classified as either clone, adaptation/ upgrade, or new. A clone is a copy of an existing attraction at another Disney park. An adapted attraction is one that appropriated a ride mechanism from another Disney park but changed its thematic structure. For example, Hunny Pot Spin is a Winnie the Pooh reimagining of the classic Mad Tea Party (Alice in Wonderland) teacups ride. An upgrade is an attraction that has been significantly altered from previous versions with new narratives, animatronics, music, physical sets, vehicles, and/or digital effects. For example, Peter Pan's Flight at SHDL has been upgraded with a contemporary reinterpretation of the classic songs, four-person carriages instead of the traditional two, and new show scenes 
and digital effects. New means the attraction is unique to SHDL. The attraction list does not include Disney character meet-and-greets, which are often ephemeral due to the fluctuating demands of corporate synergy with the Disney film studio and the need for flexible space within the park. Disney's co-option of Chinese symbols notes any cultural components meaningful to the local audience in the attraction. A Mandarin Chinese dialogue track is not considered a noteworthy Chinese symbol as use of local language is pro forma in international theme park attractions. The last column logs whether the attraction is distinctly American in its setting, narrative, presentation, and/or character(s). For example, Peter Pan, created by a Scottish author, is clearly not considered American with ride scenes taking place in London and Neverland, and neither is Snow White with roots as a continental European fairy tale. Mickey Mouse can be considered an American icon and symbol (Apgar 2015), but Buzz Lightyear's ride takes place in space with no reference to its Toy Story setting in American suburbia with cowboy Woody.

\section{Analysis}

\subsection{Sentimentality and emotional memory}

The Chinese symbols peppered through the park are "distinctly Chinese" to trigger warm and positive cultural memories. Mandarin Chinese is spoken by SHDL's front-line workers and used as the common language for almost all attraction dialogues. Chinese food and beverages are readily available in the park. Of the 28 attractions in the park, eight can be considered to contain Chinese symbolism. Four depict Hua Mulan (Figure 1), the fabled woman warrior of China, who was the hero of a 1998 Disney animated feature film (with a live action Disney film version scheduled for release in 2020). The Enchanted Storybook Castle not only features a marble bas relief portrait of Hua Mulan embedded in the wall (along with other Disney princesses), but the castle's decorations feature Chinese elements such as dragons (symbolic of strength and good fortune), jade, dragonflies (associated with harmony), pearls, and a peony flower as the finial. The Garden of the Twelve Friends displays the signs of the Chinese zodiac as Disney characters (e.g. the rabbit is represented as Thumper from the 1942 film Bambi, the rat is represented as Remy from the 2007 film Ratatouille, etc.; Figure 2), and the Frozen SingAlong show incorporates traditional Chinese string instruments into the film's famous songs. The Tarzan: Call of the Jungle production is staged by a 


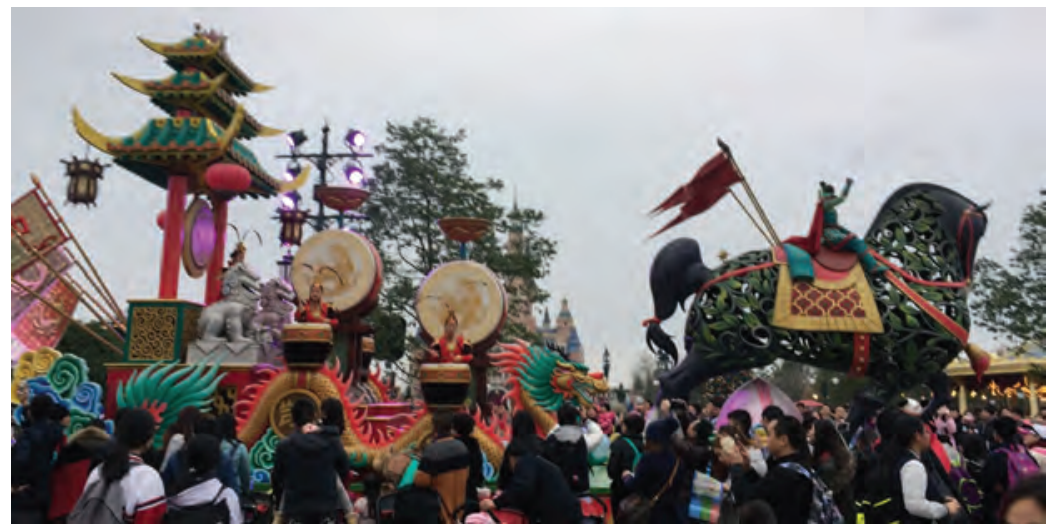

Figure 1: Hua Mulan on a giant warhorse at the SHDL parade. (Photo by authors, taken in November 2016.)

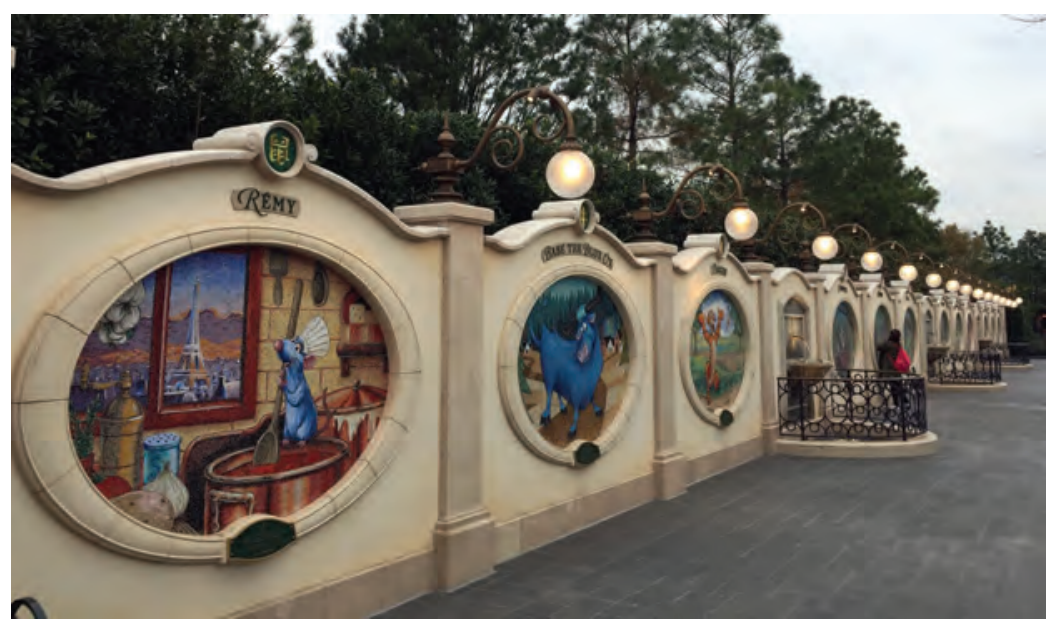

Figure 2: Garden of the Twelve Friends representing Disney characters as Chinese zodiac signs. (Photo by authors, taken in November 2016.)

Chinese director as an acrobatic spectacle (Barboza and Barnes 2016). The flight motion simulator Soaring Over the Horizon is a completely reimagined and reshot film inspired by the original American version called Soarin' Over California. On the same day Horizon debuted in SHDL, the original California film was also replaced at Disney's US parks by Horizon, but with a crucial difference. While all versions of Horizon take riders on a virtual journey to some of the planet's most iconic sights including the Taj Mahal, Great 
Pyramids, Eiffel Tower, Great Wall, and Neuschwanstein Castle, the ride journey's final show scene in SHDL diverges from the American ending, which features fireworks over Disneyland in California, and Epcot in Florida. Instead at SHDL, the ride culminates in fireworks over the Shanghai skyline featuring the World Financial Center and Oriental Pearl. The Horizon film at SHDL bookends the Great Wall of China as a symbol of China's might and majesty in the past while the finale showcases China's wealth and wonders in the present.

\subsection{Socialization}

Disney parks have always been designed with families foremost in mind as Walt Disney created Disneyland as a place where parents and children could have fun together (Gabler 2006). For Chinese grandparents at SHDL needing a place to take a break and relax while visiting with their extended family, the spacious 11acre Gardens of Imagination in front of the castle features indigenous trees from all over China so locals can recall thousands of years of traditional Chinese pleasure gardens designed for contemplation, enjoyment, and socializing (Wang 1998; Valder 2002). The gardens are themed to music (Melody Garden), love (Romance Garden), and nature (Woodland Garden). Thoroughfares throughout the park are wide and spacious to accommodate visitors comfortably even on crowded days. For family members without adventurous palates, 70\% of SHDL's restaurants have Chinese food on the menu (McDonald 2016). Restaurants were designed with more seating than at previous Disneylands as research showed Chinese visitors were more likely to linger after a meal (Tribune News Service 2016). There are also large picnic areas for families to bring their own meals (Figure 3). Disney added more shows and live entertainment in lieu of adrenalin pumping thrill rides in order to satisfy older Chinese family members (Tribune News Service 2016).

\subsection{User-derived benefits}

Art historian Karal Marling (1997), legendary Disney Imagineer John Hench (2003), and Disney's The Imagineers (2010) consider the quintessential Disneyland experience to be one of reassurance for the visitors. For example, Main Street in the US Disney parks symbolizes purity and innocence for Americans (Francaviglia 1996), while providing an enhanced reality and escape from a troubled world (Hench 2003; Findlay 1992). To accomplish this 


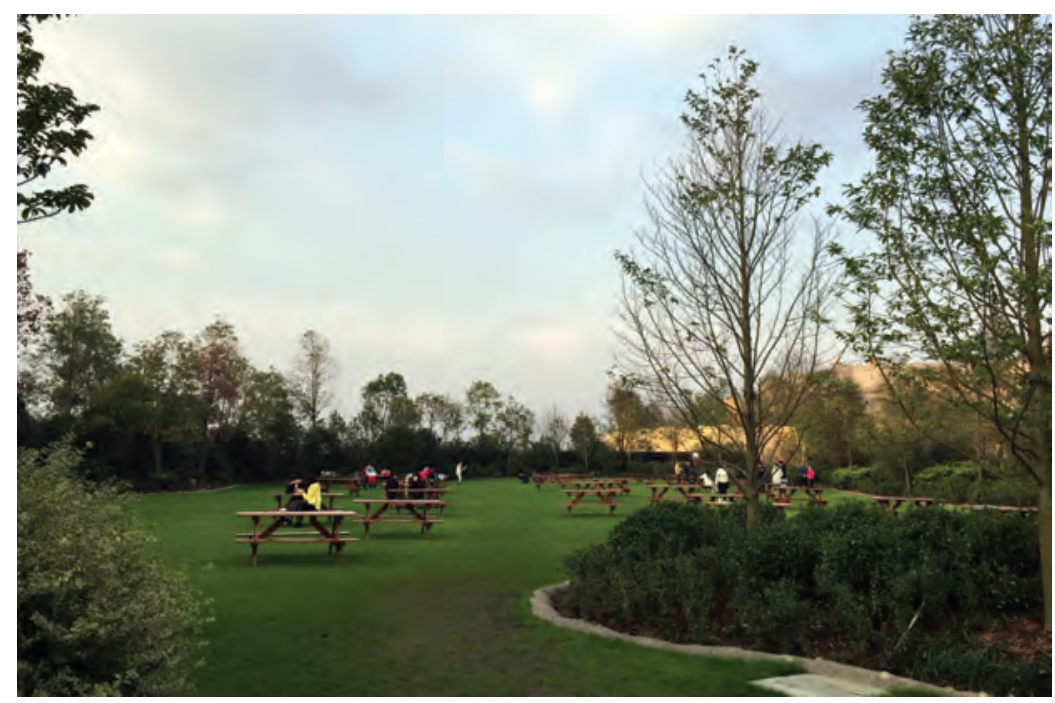

Figure 3: Ample space for picnics, relaxing, and socializing at SHDL. (Photo by authors, taken in November 2016.)

pleasing atmosphere in Shanghai, the park had to be designed to speak to Chinese visitors while remaining a recognizably Disney environment.

"Authentically Disney" in SHDL's attraction list includes characters and stories originating with Disney such as Pirates of the Caribbean, Mickey Mouse, Fantasia, Stitch, Buzz Lightyear, and TRON, and those licensed, purchased or taken from the public domain such as Dumbo, Snow White, Tarzan, Winnie the Pooh, Alice in Wonderland, and Peter Pan. These characters and stories form as textual accoutrements throughout the park reminding visitors of their previous Disney media experiences, but do not necessarily create the classic Disneyland sense of security and reassurance. To accomplish this feeling at SHDL, attractions from previous Disneylands with problematic intertextual associations were not transplanted to Shanghai. The Jungle Cruise attraction of previous Adventurelands, with its postcolonialism (Malia Hom 2013; Bryman 2004) and “colonial racism” (Fjellman 1992: 225) was not imported to SHDL. Other popular Disney park attractions not present due to potentially problematic narratives include Indiana Jones for post-colonialism (Shaheen 2014), Splash Mountain for being derivative of the racially controversial 1946 Disney film Song of the South (Sperb 2012), It's a Small World for whitewashed homogenization (Malia Hom 2013), and the entirety of Frontierland for American imperialism (Francaviglia 2011). One of Walt Disney's most beloved attractions, the Disneyland Railroad (Gennawey 2014), is missing from SHDL, perhaps due to its 
intertextual association with the exploitation of Chinese-American labor building the US transcontinental railroad in the nineteenth century and the 1882 Chinese Exclusion Act (the only time in US history a particular ethnic group was singled out for zero immigration; Takaki 1998). Most of SHDL's attractions are located in fantastic spaces normally inaccessible to humans such as inside a computer (TRON), Wonderland (Alice), a cartoon planet (Buzz Lightyear), the Hundred Acre Wood (Winnie the Pooh), Neverland (Peter Pan), and a dwarven mine (Snow White and the Seven Dwarfs). The Main Street USA of previous Disneylands became SHDL's Mickey Avenue, a warmly whimsical thoroughfare featuring classic Disney characters Mickey and Minnie Mouse, Donald Duck, Goofy, and Pluto (Figure 4). Main Street was an idealized reconstruction of Walt Disney's boyhood hometown of Marceline, Missouri, but SHDL's Mickey Avenue comprises no earthly geographic referent for it is where toons live, not people. River rapid attractions in previous Disney parks could be identified geographically as California for Grizzly River Run in Disney California Adventure, and Asia for Kali River Rapids in Disney Animal Kingdom, but SHDL's Roaring Rapids has no identifiable earthen placeholder. The attraction's backstory locates it where the Earth connects to the sky on a magical island called Arbori, a place unconnected to any previous Disney texts thereby functioning as an empty signifier inoffensive to everyone since it has no referent or meaning. Riders are informed they are heading upriver to Field Camp Beta, an imagined non-place (Augé 1995) devoid of any historical or social context. The only defined earthly locale in SHDL is the land Treasure Cove. While China has a colorful and long pirate history from the sixteenth through nineteenth centuries (Anthony 2003; Murray 1987), Disney themed Treasure Cove to an eighteenth-century Spanish harbor town in the Caribbean to tie the land in corporate synergy to the Johnny Depp films. The Pirates of the Caribbean attraction at SHDL is an entirely new narrative and aesthetic interpretation apart from the Pirates attractions at previous Disneylands. SHDL's Pirates is based on the series of films that premiered in 2003, whose initial inspiration was from the original 1967 Pirates attraction in Disneyland. By locating attraction narratives primarily in fantasy locales or unidentifiable places, Chinese visitors need not make any unsettling intertextual associations. This "authentically Disney" experience at SHDL functions as a respite, reassurance, and relief from one's troubles and tribulations left outside the Disneyland park gates in the real world.

\subsection{Traditional customer outcome}

To emphasize SHDL's unique differentiation compared to previous Disneylands, CEO Iger crafted a dedication speech unlike any given before. In front of the enormous Enchanted Storybook Castle (Figure 5) on opening day, 16 June 2016, 


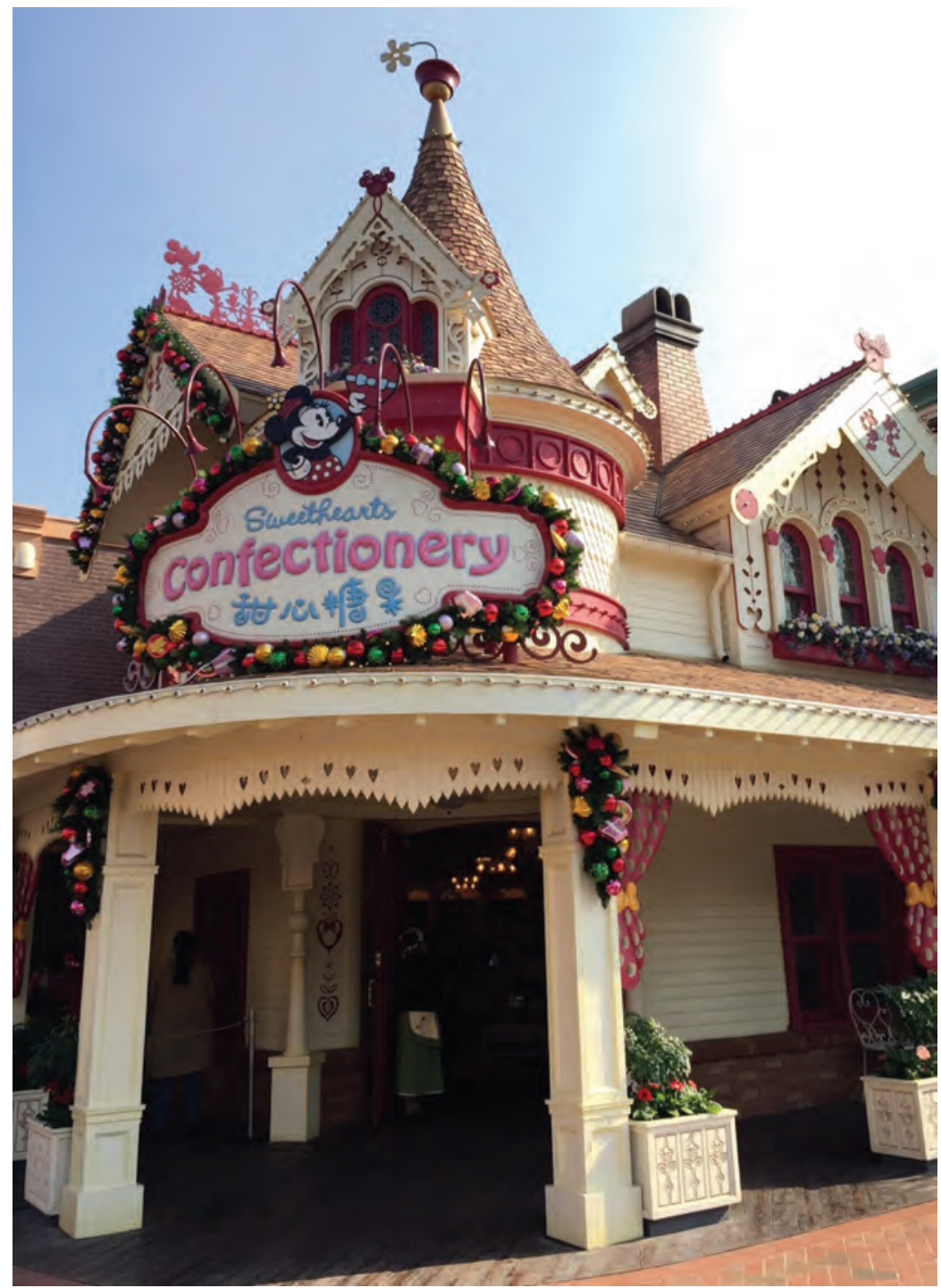

Figure 4: Minnie Mouse's Confectionery on SHDL's Mickey Avenue. (Photo by authors, taken in November 2016.)

Iger spoke for three and a half minutes (Walt Disney's 1955 Disneyland dedication was only 26 seconds) heralding the new park as "a one of a kind experience that is authentically Disney and distinctly Chinese." He noted the park’s music, 


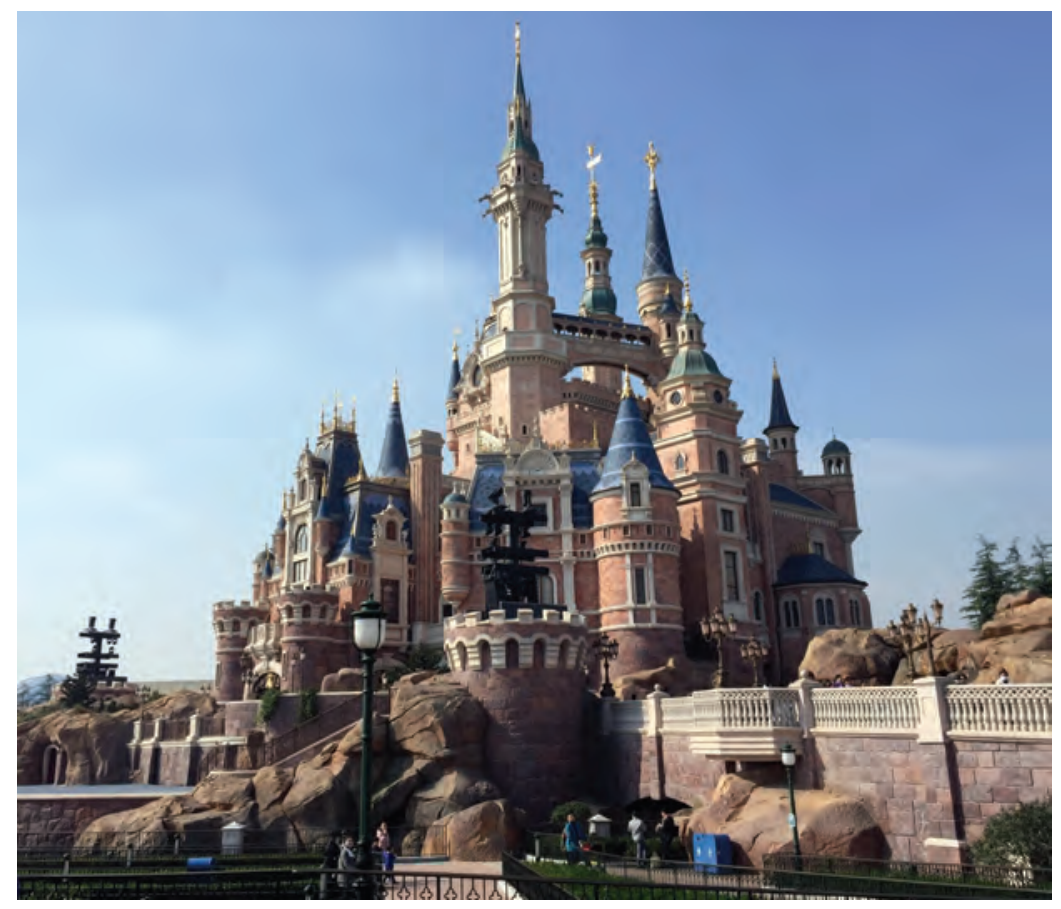

Figure 5: Enchanted Storybook Castle at SHDL. (Photo by authors, taken in November 2016.)

including a score exclusively created for SHDL by noted Chinese composer and conductor Tan Dun, combined the best of China and Disney "for great friendship and shared dreams." The park was ready to be "shared with the people of China" and to "welcome the whole world." Iger celebrated corporate heritage by invoking the memory of company founder, Walt Disney, and the workers who made SHDL coming "from China, the United States and around the world." He recited a Chinese idiom, declared excitement to be a part of China's dynamic future, and hoped the park would bring joy to the Chinese people for generations to come. His one and only mention of America came in relation to thanking the SHDL project workers. In contrast, during the dedication of TDL in 1983, the chair of the Disney board, L. Cardon Walker, said, "And may this magical kingdom be an enduring symbol of the spirit of cooperation and friendship between the great nations of Japan and the United States of America." For Paris in 1992, the grand opening highlighted European transnationalism, as the park was originally called Euro Disneyland, and celebrated the partnership of the Old World of Europe and the New World of America (Lainsbury 2000). At 
the dedication of HKDL in 2005, CEO Eisner and Hong Kong Chief Executive Donald Tsang announced, "Hong Kong Disneyland is dedicated to the young and the young at heart - with the hope that it will be a source of joy and inspiration, and an enduring symbol of the cooperation, friendship and understanding between the people of Hong Kong and the United States of America." When opening previous international parks, the audience heard dedications emphasizing friendship and cooperation between two countries or peoples engineered as a partnership through Disney. What the Chinese audience in Shanghai heard on opening day was SHDL as a partnership between China and Disney, without America. The message from Iger was clear that this was not Disneyland in China, but China's Disneyland as a category-defining entity. Disney, long seen as a quintessentially American brand around the world (Wasko et al. 2001), purposely detached itself from its country of origin to be construed by the Chinese people and government as a Chinese park (with the Shanghai Shendi Group's ownership staked at 57\% and Disney at 43\%). Shortly after the park's opening, Iger, in a US newspaper interview, said he wanted a Shanghai Disneyland that, "not only could [Chinese visitors] relate to it, but they could be proud of it and could have a sense of ownership" (Levine 2016). The establishment of a Disneyland in a new country was no longer a partnership between peoples of two nations. Rather this was a new kind of partnership between a country, China, and a company, Disney, to foster an emotional branding that would resonate with the Chinese people.

From Table 1, only a little under $30 \%$ of the park's attractions contain Chinese symbols, which is considerable but does not add up to a distinct Chinese appearance for much of the park. What is "distinct" are the $80 \%$ of the park's attractions different from previous Disneylands. It is SHDL as a whole that is distinct in the sense that SHDL is a Disneyland distinct to China. The Hong Kong park was problematic because "Disney did not conceive of the park as Hong Kong Disneyland, but rather as Disneyland in Hong Kong” (Fung and Lee 2009: 202). Disney learned a lesson from Hong Kong and Paris, to create a distinct Disney park in Shanghai unlike any of the previous Disneylands with attractions unique or significantly upgraded and/or adapted from previous iterations. "Distinctly Chinese" signifies SHDL as a global novelty.

\subsection{Superior marketing characteristics}

After China's falling out with the Eisner-era Disney over the film Kundun, Iger took over in 2005 as CEO with a renewed focus not only on establishing business ties, but also establishing a positive association for the Disney brand and texts 
in China. The 2008 rollout of Disney English centers (currently in nine Chinese cities), saw the use of the company's characters and stories to teach children English, and thereby familiarize the youngest generation with Disney texts. In 2015, the world's largest Disney store opened in the Pudong financial district of Shanghai (Forgione 2015); and, in 2016, Disney announced a plan to start making Disney-branded movies in China, and claimed four of the five spots for highest grossing imported films in the country (Bloomberg 2016a). Disney also began working with China's Ministry of Culture to develop the Chinese animation industry (Barboza and Barnes 2016). By SHDL's opening in mid-2016, the 330 million Chinese people within a three-hour drive of the park (McDonald 2016) had been primed on Disney.

SHDL is semiotically designed to be marketed and perceived as the New. Citing Halliday's (1985) work on English language structure and intonation patterns as constructed to provide information that is already known at the beginning, and the new at the culmination of a text group, Kress and Van Leeuwen (2006) discussed the linguistically-inspired role of sequence in information composition as the Given and the New. Since English is read from left to right (as is modern Chinese), English speakers position that which is familiar and known on the left as the Given, and that which is not yet known on the right as the New. This dyad is commonly used in everything from Shannon and Weaver's (1949) well-known "source>message > destination" model to "before and after” weight loss advertisements in periodicals (Ling and Zuraidah 2013).

The physical arrangement of lands in previous Disneylands was also arranged in a Given-New relationship. All visitors entered through Main Street arriving at the central hub's points of departure in front of the castle. To the left was Adventureland set in a 1930s European colonial environment, and Frontierland as a nineteenth century Wild West gold rush town. Center through the castle awaited Fantasyland with its European fairy tale inspired attractions. On the right beckoned Tomorrowland with its attractions showcasing a future full of progress through science. Therefore, the Given depicted the past as 1800s Western and 1930s colonialism, while the New highlighted outer space and technology.

For SHDL, Disney flipped the usual physical placement of the lands and thus the temporal order that was common to all previous Disneylands. In Shanghai, Tomorrowland became the Given, and Adventure Isle and Treasure Cove became the New. Other lands remained in their customary locations with SHDL's Main Street style thoroughfare, Mickey Avenue, still the first and last land that park visitors pass through at park entrance and exit, and Fantasyland ensconced in the center behind the castle. While Disney Imagineers might have switched the usual placement of lands due to the environmental suitability for planned attractions in each area, SHDL's visitors are still confronted by the underlying social semiotic. By 
placing tomorrow as the Given in SHDL, Disney assigns the future as already manifest in China. Attractions unique to SHDL in Tomorrowland feature the chance for visitors to fly with jet packs or ride futuristic lighted motorcycles inside a giant computer themed to the TRON films and housed within a huge blue and silver, glass and steel lattice carapace (Figure 6). The name of the land in Chinese is literally Tomorrow-world (明日世界), not -land, implying a broader worldly expanse of experiences for Chinese visitors in the future, which is the now in China.

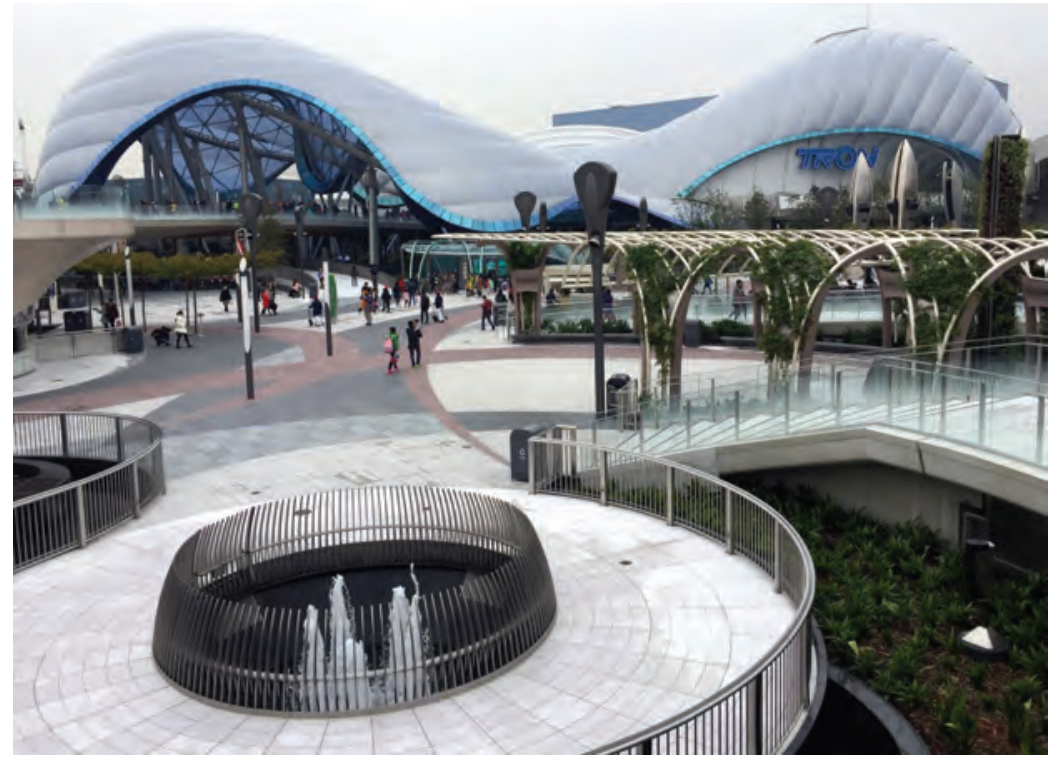

Figure 6: SHDL Tomorrow-world (明日世界). (Photo by authors, taken in November 2016.)

Occupying the New position in Shanghai is Treasure Cove and Adventure Isle. The Spanish Caribbean is the New for Chinese visitors, who may some time in the future take a Disney cruise to the company's exclusive private island, Castaway Cay, in the Bahamas. In Adventure Isle, Chinese visitors can take a virtual ride around the world in Soaring Over the Horizon to Germany, the United States, Fiji, Australia, France, Argentina, India, Egypt, and other locales. The New is Chinese consumers as global tourists.

In contrast to Shanghai, the Tomorrowland attractions of the US parks are considered so outmoded that some American fans derisively designate the area "Yesterland." The Tomorrowlands of the two American Disneylands still feature the Autopia attraction where visitors drive gas-powered cars on the freeways of 
tomorrow, circa 1955 when the attraction premiered in California. The early history of Tomorrowland in CADL featured many corporate sponsors for science-themed, World's Fair type exhibits such as the Monsanto Hall of Chemistry, Crane Company Bathroom of Tomorrow, and the Dutch Boy Color Gallery. Other attractions underscored the Space Race of the 1950s and 1960s with Rocket to the Moon (which became Mission to Mars in 1975) and the Flying Saucers (single-rider discs that careened on a gigantic air hockey table). In the 1960s Disney debuted the last of the major science-themed attractions with Adventures Thru Inner Space (a Monsanto sponsored dark ride to view the world from the perspective of an atom) and the Carousel of Progress (a General Electric sponsored rotating theater showcasing a perpetually better tomorrow through technology). Beginning in the 1980s, Tomorrowland shifted to space fantasy attractions such as Michael Jackson's Captain Eo Adventure 4D film, a Star Wars motion simulator, and a Buzz Lightyear (of Toy Story) shooting dark ride. Though Tomorrowland still stands in the New position in all Disney parks except Shanghai, they are now temporally disconnected exhibiting a hodgepodge of space fantasy, anthropomorphic toys, and archaic transportation. SHDL's Tomorrowland stands alone as the New.

\section{Discussion}

The analysis of SHDL's historical development, design, and discourse through the five antecedents of emotional branding point toward a new direction for Disney's international parks. No longer moored to America, SHDL is China's Disneyland. Disney not only used Chinese symbols within particular aspects of the park, but, more importantly, calibrated each attraction to delete or, at least, minimize reference to America and/or problematic Eurocentric narratives. The memory of Western powers, including the US, imperialistically bullying China during what the Chinese call "the 150 years of shame and humiliation" (18001949) of Opium Wars, Unequal Treaties, and territorial/economic concessions still burns in the Chinese collective consciousness. The lack of overt Americanism and American character throughout the park's attractions abides the classic Disney semiotic of reassurance and comfort through architecture. Disney's emotional branding of SHDL has positioned China's Disneyland as the distinct and the New.

A closer look at the six attractions in Table 1 that include American content demonstrates the narrow and nebulous scope of some of the American references. In Soaring Over the Horizon, the sandstone buttes of Monument Valley, 
Utah, are on screen for only 17 seconds (the entire film is four and a half minutes in length). Furthermore, the place is not identified during the film, so unless a viewer is already familiar with the setting, one would be unaware of its exact locale in America. Three attractions include Mickey Mouse as American content, though he could be considered as much, if not more, a Disney corporate symbol (Wasko 2001; Danesi 2006) than an American icon. The Enchanted Storybook Castle displays portraits of the American princesses Pocahontas (Native American) and Tiana (African-American), but they are only two of a dozen princesses featured in the building. And the castle's featured walkthrough attraction focuses on a European Disney princess, Snow White. By looking at the attraction content closely, America in SHDL is even less visible than the already low attraction tally in the table would indicate.

Many of the attractions from previous Disneylands not transferred to SHDL stand out for their American character. All Disneylands had a Western themed land, and as recently as 2012, Disney opened a Frontierland style land in Hong Kong called Grizzly Gulch. SHDL is the only Disneyland without the characteristically American Frontierland. Noticeably absent from SHDL are classic Disney attractions that are overtly American or culturally imperialistic but still available in other international Disneylands: Jungle Cruise (TDL, HKDL), Indiana Jones (TDL), Splash Mountain (TDL), It's a Small World (TDL, DLP, HKDL), Haunted Mansion (TDL, DLP), Big Thunder Mountain Railroad (TDL, DLP, HKDL's Big Grizzly Mine Cars), and Enchanted Tiki Room (TDL). Figure 7 presents a semiotic square (Greimas 1984 [1966]) to illustrate the brand positioning of Disney's international parks. Previous international Disneylands straddled the line of local and American, which worked in Tokyo but faltered in Paris and Hong Kong. To induce an emotional branding effect with Chinese visitors, Disney crafted SHDL as local and not American.

\section{Conclusion}

SHDL saw 5.6 million visitors in its first six months of operation (Wei 2017), which is almost equal the 6.1 million visitors HKDL attracted for the entire fiscal year 2016 (Hong Kong Disneyland 2017). In SHDL’s first year of operation, the park topped 11 million visitors, which exceeded Disney's projections (Yoon 2017). The formation, positioning, and execution of Disney's emotional branding strategy for SHDL has been successful so far, but some Chinese are still wary of Western influence. At a March 2016 gathering of political leaders in Beijing, an Anhui province deputy head of culture warned, "I suggest that we shouldn't 


\section{Semiotic Square of International Disneylands}

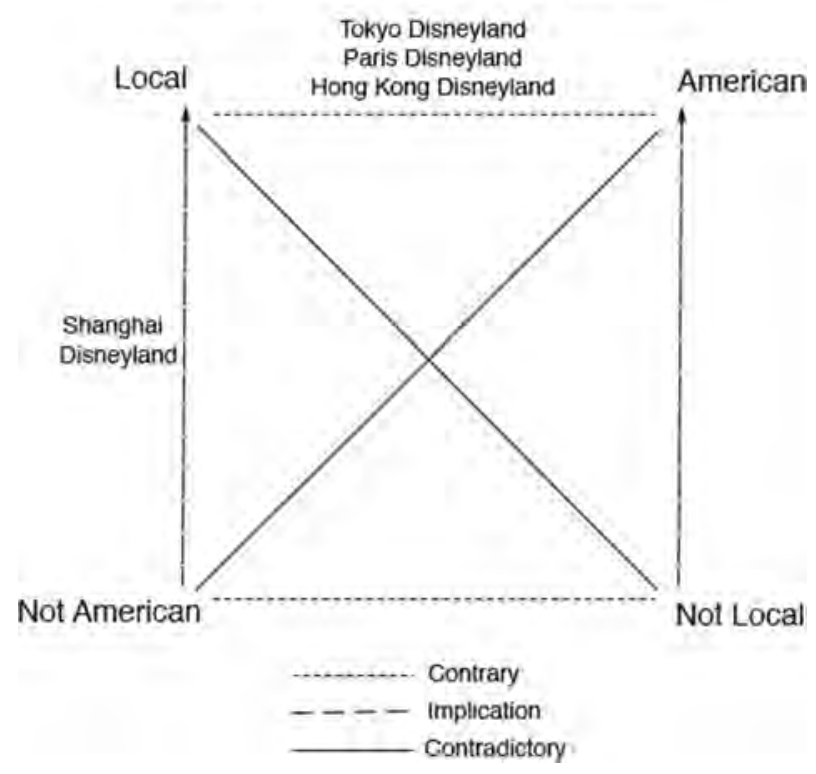

Figure 7: Shanghai Disneyland repositioning compared to previous international Disneylands.

allow too many Disneyland theme parks to be built. If children follow Western culture when they are little, they will end up liking Western culture when they grow up and be uninterested in Chinese culture" (Barboza and Barnes 2016). Chinese visitors have also complained about the high prices for food in the park (Xinhua 2016). There are also Chinese companies that see Disney as a foreign competitor on their domestic turf. Wang Jianlin, the richest man in Asia and owner of the Dalian Wanda Group (China's largest real estate developer and the world's largest movie theater operator), planned to build 15 multi-billion-dollar theme parks in China to act as a "pack of wolves" to take down the one Disneyland "tiger" in Shanghai (Bloomberg 2016b). Wang dismissed the era of blindly following Mickey Mouse and Donald Duck as over, which Iger called "patently absurd" (Barboza and Barnes 2016). However, in July 2017, Wang's debt-ridden company was forced to sell off its theme park developments and other tourism assets, thus diminishing a large domestic competitor to Disney (Bradsher 2017). International theme park companies such as Universal, Merlin (owner of Legoland), SeaWorld, and Six Flags all have agreements to open parks in China. 
Another challenge for SHDL's emotional branding comes from the Trump administration in the United States. As Disney attempts to obfuscate its American roots in a bid for acceptance as a gracious and respectful partner for China, Trump's America-first nationalism and premium on loyalty could complicate Disney's image-making maneuverability, especially since Iger was a major supporter and fund-raiser for Hillary Clinton's 2016 presidential campaign (Gardner 2016). If President Trump carries through with campaign rhetoric to initiate a trade and currency war with China or sparks a military conflict in North Korea or with the Chinese navy in the South China Sea, then Disney and SHDL could become targets of Chinese protests and boycotts as South Korea experienced with the deployment of the THAAD anti-missile defense systems in 2017, Japan experienced in 2012 after a territorial dispute with China over the Senkaku/Diaoyu islands, and the US experienced in 1999 after the bombing of the Chinese embassy in Belgrade, Yugoslavia. Disney also needs to watch for backlash from American fans, who took note of the billions spent creating SHDL, and pushed back at what they considered Disney's lavish attention to China with a sarcastic Twitter hashtag campaign of \#ThanksShanghai blaming SHDL for a lack of investment and cutbacks at American Disney parks (Niles 2016).

Disney's emotional branding strategy for SHDL will continue to undergo tests as it navigates a tightrope between the potentially resurgent nationalism of the governments and people of China and the US. The approach Disney took in China departed significantly from the Tokyo, Paris and Hong Kong partnerships between governments and peoples, but the new positioning has earned financial benefits for the company thus far. Disney set a foundation in SHDL that fulfilled the antecedents for a successful emotional branding: sensory memory through Chinese symbolism, consideration of family socialization, user benefit through a sense of reassurance and desired self image, traditional customer outcome by unique differentiation, and superior marketing by focusing and setting China and SHDL as the New.

\section{References}

Antony, Robert. 2003. Like froth floating on the sea: The world of pirates and seafarers in late imperial south China [Institute for East Asian Studies, China Research Monographs 56]. Berkeley: University of California Press.

Apgar, Garry. 2015. Mickey Mouse: Emblem of the American spirit. San Francisco: Walt Disney Family Foundation Press.

Areddy, James \& Ben Fritz. 2016. Five thing to know about Disney in China. Wall Street Journal, June 9. http://blogs.wsj.com/briefly/2016/06/09/5-things-to-know-about-disney-inchina/(accessed 14 March 2017). 
Atkin, Douglas. 2004. The culting of brands: When customers become true believers. New York: Portfolio.

Augé, Marc. 1995. Non-places: Introduction to an anthropology of supermodernity. London: Verso. Bakhtin, Mikhail. 1986. The problem of speech in genres. In C. Emerson \& M. Holquist (eds.), Speech genres and other late essays, 60-102. Austin: University of Texas Press.

Barboza, David \& Brooks Barnes. 2016. How China won the keys to Disney's Magic Kingdom. New York Times, October 22. https://www.nytimes.com/2016/06/15/business/interna tional/china-disney.html (accessed 12 March 2017).

Bloomberg News. 2016a. Coming to a theater near you: Made-in-China Disney movies. South China Morning Post, June 9. http://www.scmp.com/business/article/1971051/comingtheatre-near-you-made-china-disney-movies (accessed 14 March 2017).

Bloomberg News. 2016b. Wanda seeks to overrun Disney in theme park battle in China. Bloomberg, September 26. https://www.bloomberg.com/news/articles/2016-09-25/ wanda-s-wang-wants-to-overrun-disney-in-china-theme-park-battle (accessed 14 March 2017).

Bowlby, John. 1969. Attachment and loss [Attachment 1]. New York: Basic.

Bradsher, K. 2017. Debt-ridden Chinese giant now a shadow of its former size. New York Times, August 1. https://www.nytimes.com/2017/08/01/business/dalian-wanda-group-chinadebt.html (accessed 3 August 2017).

Brannen, Mary Yoko. 1992. Bwana Mickey: Constructing cultural consumption at Tokyo Disneyland. In Joseph Tobin (ed.), Remade in Japan, 216-234. New Haven: Yale University Press.

Brannen, Mary Yoko. 2004. When Mickey loses face: Recontextualization, semantic fit, and the semiotics of foreignness. Academy of Management Review 29(4). 593-616.

Bryman, Alan. 2004. The Disneyization of society. London: Sage.

Cheung, Ming. 2012. The branding of a quality liquor as a symbolic effort toward bringing China forward culturally: A comparative study of Wuliangye and Absolut Vodka. Semiotica 192(1/4). 471-499.

Choi, Kimburley. 2010a. Remade in Hong Kong: How Hong Kong people use Hong Kong Disneyland. Saarbrüken: Lambert.

Choi, Kimburley. 2010b. Constructing a decolonized world city for consumption: Discourses on Hong Kong Disneyland and their implications. Social Semiotics 20(5). 573-592.

Danesi, Marcel. 2006. Brands. New York: Taylor \& Francis.

Fairclough, Norman. 1992. Discourse and social change. Cambridge: Polity Press.

Findlay, John. 1992. Magic lands: Western cityscapes and American culture after 1940. Berkeley: University of California Press.

Fjellman, Stephen. 1992. Vinyl leaves: Walt Disney World and America. Boulder, CO: Westview.

Forgione, Mary. 2015. Nine things you need to know about the world's biggest Disney Store. Los Angeles Times, May 22. http://www.latimes.com/travel/la-trb-disney-store-china20150521-htmlstory.html (accessed 14 March 2017).

Fournier, Susan. 1998. Consumers and their brands: Developing relationship theory in consumer research. Journal of Consumer Research 24(4). 343-374.

Francaviglia, Richard. 1996. Main street revisited: Time, space, and image-building in small town America. lowa City: University of lowa Press.

Francaviglia, Richard. 2011. Frontierland as an allegorical map of the American West. In Kathy Jackson \& Mark West (eds.), Disneyland and culture: Essays on the parks and their influence, 59-86. Jefferson, NC: McFarland. 
Frank, Thomas. 1997. The conquest of cool: Business culture, counterculture, and the rise of hip consumerism. Chicago: University of Chicago Press.

Frater, Patrick. 2016. Shanghai Disneyland to add Toy Story land. Variety, November 9.http:// variety.com/2016/biz/asia/shanghai-disneyland-to-add-toy-story-land-1201914430/ (accessed 25 March 2017).

Fung, Anthony Y. H \& Micky Lee. 2009. Localizing a global amusement park: Hong Kong Disneyland. Continuum 23(2). 197-208.

Gabler, Neal. 2006. Walt Disney: The triumph of the American imagination. New York: Vintage. Gardner, Chris. 2016. Disney's Bob Iger among hosts of Hillary Clinton fundraiser at Haim Saban's house. Hollywood Reporter, July 20. http://www.hollywoodreporter.com/news/ disneys-bob-iger-hosts-hillary-913028 (accessed 16 March 2017).

Gennawey, Sam. 2014. The Disneyland story. Birmingham, AL: Keen.

Gobe, Marc. 2001. Emotional branding: The new paradigm for connecting brands to people. New York: Allworth Press.

Greimas, Algirdas. 1984 [1966]. Structural semantics: An attempt at a method Daniele McDowell, Ronald Schleifer \& Alan Velie (trans.). Omaha: University of Nebraska Press.

Grisaffe, Douglas \& Hieu Nguyen. 2011. Antecedents of emotional attachment to brands. Journal of Business Research 64. 1052-1059.

Halliday, Michael. 1985. An introduction to functional grammar. London: Edward Arnold. Hench, John. 2003. Designing Disney: Imagineering and the art of the show. New York: Disney. Hong Kong Disneyland. 2016. Hong Kong Disneyland annual business review for the fiscal year 2015. http://ahongkongdisneyland.disney.go.com/media/hkdlcorp_v0100/en_US/ aboutOurCompany/AnnualBusinessReview15.pdf (accessed 7 March 2017).

Hong Kong Disneyland. 2017. Hong Kong Disneyland annual business review for the fiscal year 2016. http://ahongkongdisneyland.disney.go.com/media/hkdlcorp_v0100/en_US/ aboutOurCompany/AnnualBusinessReview16.pdf (accessed 7 March 2017).

The Imagineers. 2010. Walt Disney imagineering. New York: Disney.

Kress, Gunther \& Van Leeuwen. Theo. 2006. Reading images: The grammar of visual design, 2nd edn New York: Routledge.

Lainsbury, Andrew. 2000. Once upon an American dream: The story of Euro Disneyland. Lawrence, KS: University Press of Kansas.

Lemke, J. L. 1992. Intertextuality and educational research. Linguistics and Education 4. 257-267. Levine, Arthur. 2016. Bob Iger: Shanghai Disney isn't just Disneyland in China. USA Today, June 23. http://www.usatoday.com/story/travel/experience/america/2016/06/23/bob-igerinterview-shanghai-disney-resort-opening/86253624/(accessed 16 March 2017).

Ling, Emily \& Don Zuraidah. 2013. Fat stigmatization in slimming advertisements in Malaysia. Search 5(2). 1-18.

Malia Hom, Stephanie. 2013. Simulated imperialism. Traditional Dwellings and Settlements Review 25(1). 25-44.

Marling, Karal Ann. 1997. Imagineering the Disney theme parks. In K. A. Marling (ed.), Designing Disney's theme parks: The architecture of reassurance, 29-177. Montreal: Canadian Centre for Architecture.

McDonald, Brady. 2016. Everything you need to know about Shanghai Disneyland. Los Angeles Times, January 27. http://www.latimes.com/travel/themeparks/la-trb-shanghai-disney land-preview-20160127-story.html (accessed 27 March 2017).

Morrison, Sharon \& Frederick Crane. 2007. Building the service brand by creating and managing an emotional brand experience. Journal of Brand Management 14(5). 410-421. 
Murray, Dian. 1987. Pirates of the South China coast, 1790-1810. Stanford: Stanford University Press.

Niles, Robert. 2016. Don't blame Shanghai for cuts at Disneyland and Disney World. Theme Park Insider, April 3. http://www.themeparkinsider.com/flume/201604/5017/(accessed 16 March 2017).

Oswald, Laura. 2012. Marketing semiosis. Oxford: Oxford University Press.

Paltridge, Brian. 2006. Discourse analysis. London: Continuum.

Raz, Aviad. 1999. Riding the black ship: Japan and Tokyo Disneyland. Cambridge, MA: Harvard University Press.

Roberts, Kevin. 2004. Lovemarks: The future beyond brands. New York: Powerhouse.

Shaheen, Jack. 2014. Reel bad Arabs: How Hollywood vilifies a people. Northampton, MA: Olive Branch Press.

Shannon, Claude \& Warren Weaver. 1949. The mathematical theory of communication. Urbana: University of Illinois Press.

Sperb, Jason. 2012. Disney's most notorious film: Race, convergence, and the hidden histories of Song of the South. Austin, TX: University of Texas Press.

Stewart, James. 2005. Disney war. New York: Simon \& Schuster.

Takaki, Ronald. 1998. Strangers from a different shore: A History of Asian Americans. New York: Little, Brown.

Themed Entertainment Association (TEA). 2017. Theme index museum index 2016 global attractions attendance report. http://www.aecom.com/content/wp-content/uploads/ 2017/06/2016-ThemeMuseum-Index.pdf (accessed 22 July 2017).

Thompson, Craig, Aric Rindfleisch \& Zeynep Arsel. 2006. Emotional branding and the strategic value of the Doppelgänger brand image. Journal of Marketing 70. 50-64.

Thomson, Matthew, Deborah Maclnnis \& C. Whan Park. 2005. The ties that bind: Measuring the strength of consumers' emotional attachments to brands. Journal of Consumer Psychology 15(1). 77-91.

Tribune News Service. 2016. How Disney made sure Shanghai Disneyland doesn't put off Chinese visitors. South China Morning Post, July 12. http://www.scmp.com/lifestyle/tra vel-leisure/article/1988450/how-disney-made-sure-shanghai-disneyland-doesnt-put-chi nese (accessed 27 March 2017).

Valder, Peter. 2002. Gardens in China. Portland: Timber Press.

Wang, Joseph Cho. 1998. The Chinese garden. Oxford: Oxford University Press.

Wasko, Janet. 2001. Understanding Disney. Cambridge: Polity Press.

Wasko, Janet, Mark Phillips \& Eileen Meehan (eds.). 2001. Dazzled by Disney: Global Disney audiences project. New York: Leicester University Press.

Wei, Ren. 2017. Shanghai Disney riding high and on track to overtake Hong Kong "rival." South China Morning Post, June 15. http://www.scmp.com/news/china/policies-politics/ article/2062333/shanghai-disney-rides-high-first-six-months (accessed 17 March 2017).

Xinhua. 2016. Shanghai Disneyland responds to pricey food claims. China Daily, May 17. http://www.chinadaily.com.cn/china/2016-05/17/content_25328359.htm (accessed 16 March 2017).

Yoon, Eunice. 2017. Shanghai Disneyland visitors top 11 million in its first year, blowing past expectations, CEO Iger says. CNBC, June 16. https://www.cnbc.com/2017/06/16/shang hai-disneyland-visitors-top-11-million-in-its-first-year-blowing-past-expectations-ceo-igersays.html (accessed 27 July 2017). 
Copyright of Semiotica is the property of De Gruyter and its content may not be copied or emailed to multiple sites or posted to a listserv without the copyright holder's express written permission. However, users may print, download, or email articles for individual use. 